\title{
PHILOLOGY
}

\section{DEVELOPMENT OF INTERNATIONAL AND NATIONAL LANGUAGES}

\author{
Shuhrat Kuchimov, Professor of Tashkent State Law University. D. of Ph, Uzbekistan \\ Nilufar Ochilova, Independent researcher, Uzbekistan
}

DOI: https://doi.org/10.31435/rsglobal_ijitss/31082019/6619

\section{ARTICLE INFO}

Received 10 June 2019

Accepted 22 August 2019

Published 31 August 2019

\section{KEYWORDS}

international language, national language, nation, history,

Central Asia, Turcik language,

local languages,

UNESCO edition.

\begin{abstract}
The article discusses the development of international and national languages, their historical period and role in modern society. Since Uzbekistan is an independent country it is trying to increase the place of Uzbek language among other languages in the world. Currently, there are many foreigners from different countries who are interested in the history of Uzbekistan and its language. We hope that the Uzbek language will develop in the same way as other international languages.
\end{abstract}

Citation: Shuhrat Kuchimov, Nilufar Ochilova. (2019) Development of International and National Languages. International Journal of Innovative Technologies in Social Science. 5(17). doi: 10.31435/rsglobal_ijitss/31082019/6619

Copyright: (C) 2019 Shuhrat Kuchimov, Nilufar Ochilova. This is an open-access article distributed under the terms of the Creative Commons Attribution License (CC BY). The use, distribution or reproduction in other forums is permitted, provided the original author(s) or licensor are credited and that the original publication in this journal is cited, in accordance with accepted academic practice. No use, distribution or reproduction is permitted which does not comply with these terms.

Language is a social phenomenon. It's development is closely related to people's livelihoods. If peoples value and dreams are appreciated their language will be perfected and developed in any case. Therefore the unique and perfect wealth and art of each nation in its historical development is its national language.

When the national language is developed in all aspects, it will be honored to present the country to the world with pride. That's why national language is destiny, spirit and way of life of a nation. Accordingly, every nation cares for the development of their mother tongue and also tries strengthen the legal basis of development of the language.

Accordingly, each nation and country will work on the development of their own language, which will be widely used in international relations in order to somehow manage the languages of other languages. Because a national language is a symbol of the country and nation. The national language is the reason that nations living in the country, live together, live in peace and respect each other. If the language is used internationally, there is also a great opportunity for the development of the country.

Moreover, if the state receives an international status with a certain degree of economic, political, social and cultural dimension, its influence on other countries will also increase. These aspects are also reflected in the language, affecting the languages of other countries, actively using and trying to get international language status. Accordingly, the issue of the international legal status of languages has acquired an active significance in the history of mankind.

One of the most widely used language in the world is Chinese. Later this task was continued by the ancient Greek language. Alexander the Great made increase in the Greek Language from Central Asia to African countries. For over a thousand years, it was served as the official language of 
the Byzantine Empire. Later the Latin language was replaced by the international language and served as an official language in the ancient Roman Empire. After the collapse of the ancient Roman state, the Latin language did not fall from the international arena either, and it began to serve humanity as the language of science, culture and progress.

In the Islamic world, this task has been performed by the Arabic language for many centuries. In VII-VIII centuries, the Arabic language was the language of science and culture for many centuries, especially in the life of the East. It appeared as a common language from Spain to Yemen and Iraq.

The Turcik language, which was the basis of the Uzbek language before the B.C and in our era, was widely used in the East as an international language. It was widely recognized as an international language in the Far East from the Tatar Strait, in the West from the Sea of Dunay to the Mediterranean, from Siberia in the North, from India to Tibet in the South.

In the XV-XVI centuries the Turcik language was the main language on three continents: Asia, Eastern Europe and Norh Afrika, as well as in the international and interstate language.

The Italian language was used as a means of communication with the republics of the Apennine peninsula. The German language was wisely used in many German kingdoms and principality. With advent of the Austro- Hungarian Empire, the German language was used as the state language. The emergence of the United States as a state created competition between French and English languages. The US government worked hard to ensure that English was widely accepted and widely used as an international language. The French leadership in favor of French language in international relations, did not want to use of the English language widely. Initially, such a struggle was secretly clearly codified, and they were not publicly disclosed. This was clearly seen in the 1919 Versailles Treaty. French Prime Minister J. Clemenceau demanded that the conference be held only in French. British Prime Minister D. Lower George and US President W. Wilson were asked to speak to speak English, with more than 170 million people in the world speaking English. Since then, English has been used as an international language. During the history of mankind, each state sought to widely its language. Even some countries directly oppressed the issue. An example of this is the movement of Germany before the First World War. And French and English were high at that time. The XXth century was the era of the German language, so it was highly recommended that the nations of the world, especially English and French learn German. Thus, the number of languages used in international relations has increased. At the Vienna Congress of 1815, only French was used, and French and English were recognized as an international language at the 1919 Versailles Peace Conference. At the Paris Peace Conference, held in 1946, it was used as an official language in English, French and Russian. One of the most important aspects related to language problems in international relations is the question of the international legal status of languages. Because today all the languages of the world are not equally used in international relations. Some of them are used internationally as part of the international relations, most of which are not widely used due to the lack of an international language status.

Currently, there are about six thousand languages on earth, which, according to legal status, can be divided into three types:

1. Internationally official languages (English, French, Russian, Chinese and Arabic);

2. Languages of one country with a state language (Uzbek, Indian, Turkish, Kazakh, Persian etc.)

3. Local languages (such as nenes, hakas etc.)

The United Nations recognized English, French, Spanish, Russian, Arabic and Chines as international languages and international relations are mainly implemented in these languages.

Each of the specialized UN departments has its own official language to use these languages on an equal basis.

English is used in the Food and Agriculture Organization; World Health Organization - English and French, English in the Monetary Fund, English, Spanish and French at the International Telecommunication Union; English, French and Russian and Spanish at the International Civil Aviation Organization; The International Labor Organization uses English and French as official languages.

In addition, Spanish, Arabic, Chinese and Russian languages are widely used in the United Nations International Labor Organization. International Amnesties are issued in English, French, Spanish and Arabic languages. 
The official languages of UNESCO were first English and French, then Spanish, Russian, Arabic and Chinese were adopted. In UNESCO, it is also customary to use the language of the country where the General Conference is held.

The main UNESCO edition, the UNESCO Courier, is available in thirty-five languages and is distributed worldwide.

The International Court of Justice operates in French and English languages. The Court also allows if the parties apply to the Court in their national language. In such cases, interested party answers oral questions in one of the official languages. The tribunal consists of 15 judges, from which it comes from different nationalities, and their mother tongue is also diverse. However, each of them must know the official international languages.

The members of the Council of Europe consist of 15 countries and work in 15 languages. The European Parliament has 518 seats and representatives from different countries.

The number of international and non-governmental organizations is increasing every day. They all have formal and working languages. In 1985, the Academy of International Sciences was founded in San-Marino. Espearnto, English and French are its official languages.

Obviously, language problems are of great importance in international relations, and each state tries to promote its own language in international relations. And it insists that his language is the official language in international organizations. In such cases, international practice often deals with the settlement. It also includes the working languages, not the official language of the international organization. For exemple, if the official language of the UN Working Group is English and French, the working language is Spanish, Arabic, Chinese, and Russian. In general, a lot of research has been done by world scientists in the field of international relations. They wrote numerous scientific papers, brochures and articles in this field ${ }^{1}$. A. Ostrover's special place in the "Language, Law and Diplomacy" scientific pamphlet. The focus of this brochure is to define the language and its specific features. In addition, the language of international law is also adequately investigated in scientific and technical terms. At the same time, A. Ostrover's views on the language of international law are very contradictory. Analyzing the language of international law, he agrees that neither the sovereignty of any country nor the principal of equality of a state can prevent future languages from obtaining legal status. In some countries, the official language of any language cannot be linked to the principle of sovereignty and equal rights of this state. But in most cases, the state will have its own language only if it is independent. As we know the concepts of independence and the state language are indivisible.

In the scientific literature, lawyers and linguists also conducted research in the language of law in their subjects on the subject of law. However, there is a lack of knowledge of international law in the field of science, that is, at the same time, both legal and linguistic knowledge.

The work of Ukranian professor V. I. Yuventov in this topic is remarkable. Being a lawyer and linguist, he studied the language of international law more completely and comprehensively than any other scholar. He essentially analyzed the language of international treaties in a scientific and theoretical way.

Languages of the country with the status of the official language : as an example we say that English (In USA, UK Canada), German (in Germany and Austria); French(in France); Italian (in Italy); Russian (in Russia); Spanish (in Spain); Duth (in the Netherlands); Japanese (in Japan); Korean (South Korea and North Korea); Hindi (in India); Arabic (in Arab countries); Turkish(in Turkey); and Urdu (in Pakistan). The status of these languages is strengthened in their own countries and all state activities are conducted in one language, and the state provides all the conditions for the development of these languages. This is the most important basic task of law for language development.

It is obvious that the problem of the state language in each country is important. In almost every country one or more languages are defined as state languages. All activities of the state language work in the same language. Activities in all institutions, enterprises, organizations and departments are carried out in the same language. In general, the official language is an important sign of statehood, but this does not mean that it should be the state language of the country. In some countries, the state language does not exist. However, in many developed countries, a certain language is defined as the state language. For example in Switzerland, German, French and Italian languages; Finnish and Swedish in Finland; English and French in Canada; and Austria the german language is the official

\footnotetext{
${ }^{1}$ Ostrover A. Language, Low, Diplomacy .2 vol. Philad., 1965, 963p; Moor J. Digest of International Law. Vol V, Wash. 1906.p 180
} 
language. In some countries, the languages are commonly used as the national language (English, French, Russian) are also used temporarily, including in 1950, after the independence of India, the government of India declared Hindi as the state language of the Constitution.

Since the original rights of each language can not fully resolved, the social development of the language will be violated, and difficulties will arise at the stage of its development. Without any hesitation we can see the state of the national languages in the periode of the former Soviet Union.

On October 21, 1989, the Law on the State Language of the Republic of Uzbekistan was adopted and the rights to the Uzbek language were respected. From that day, the path of development of the national language was opened. In particular, the introduction of a special article into the Constitution of the Republic of Uzbekistan that the Uzbek language is the state language has received wide recognition for the full application and development of the Uzbek language in the territory of the republic. Every state wants its language to be used as an international language.

The recognition of the language in the international arena, above all, the pride of this country. When its language is widely used by other nations, the position of the nation is also higher than that of others.

From this point of view, when the Republic of Uzbekistan was established as an independent state and established equal relations with the countries of the world, the Uzbek language was widely used in all aspects of Uzbekistan's foreign policy and now also is an important spiritual factor. 